Bernadette Sangmeister

EURO-SCEPTICAL OR EURO-PHILE?

\title{
A CRITICAL ANALYSIS OF THE JURISPRUDENCE OF THE GERMAN FEDERAL CONSTITUTIONAL COURT ON THE PROCESS OF EUROPEAN INTEGRATION AND DECISION-MAKING
}

\author{
Research Paper \\ LAWS 534: Fundamentals of European Union Law
}

FACULTY OF LAW

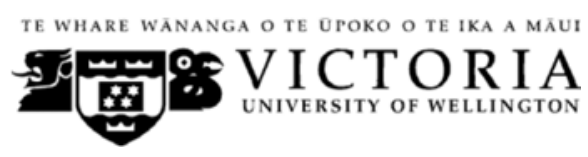

$1^{\text {st }} \quad$ Trimester 2014 


\section{Contents}

$\begin{array}{ll}\text { Abstract } & 4\end{array}$

I INTRODUCTION 5

II A STEP INTO THE RIGHT DIRECTION? FROM SOLANGE I (1974)

TO LISBON'S PRINCIPLE OF “OPENNESS TOWARDS

$\begin{array}{lr}\text { EUROPEAN LAW" (2009) } & 6\end{array}$

$\begin{array}{lll}\text { A } & \text { The Solange Jurisprudence and the Fundamental Rights Review } & 7\end{array}$

B New Challenges with New Treaties: The Jurisprudence of Maastricht

$\begin{array}{lr}\text { and Lisbon } & 8\end{array}$

III STEPPING BACKWARDS? CRITIQUING THE LIMITS ON

THE “OPENNESS TOWARDS EUROPEAN LAW” IN THE

JURISPRUDENCE AFTER LISBON (2009-2014)

10

$\begin{array}{lll}\text { A The Identity Review } & 11\end{array}$

1 Defining Constitutional Identity 12

2 Ensuring the Democratic Endorsement Process of European

$\begin{array}{ll}\text { Integration } & 13\end{array}$

$3 \quad$ A Restrictive Stance? $\quad 14$

$\begin{array}{lll}B & \text { The Ultra Vires Review } & 15\end{array}$

$1 \quad$ A Restrictive Stance Since Honeywell 16

2 Affirming or Reversing its Stance? The Impact of the Pending $\begin{array}{ll}\text { OMT Decision Case } & 17\end{array}$

(a) Background Facts of the Case 17

(b) Evaluating the Considerations Made by the FCC 18 
(c) Concluding Remarks Concerning the

“Worst Case Scenario”

$3 \quad$ Result of Analysis $\quad 23$

C A Need for Judicial Activism? Closing Remarks Concerning the Two

$\begin{array}{ll}\text { Review Competences } & 24\end{array}$

$\begin{array}{lll}\text { IV CONCLUSION } & 25\end{array}$

$\begin{array}{ll}\text { BIBLIOGRAPHY } & 27\end{array}$ 


\begin{abstract}
On 14 January 2014, for the first time in its history, the German Federal Constitutional Court (FCC) decided to refer a decision to the Court of Justice of the European Union (CJEU). This referral, which concerned the issue of the legality of the European Central Bank's bond-buying practices, must be seen as "historic" with regard to European integration and the relationship between European Union law and German constitutional law, forming part of important decisions of the FCC in this field since its first euro-critical judgment, Solange I, 40 years ago.

Considering the high influence the German Federal Constitutional Court has had on the process of European integration, this paper aims at identifying and critiquing the lines of argumentation developed by the FCC in recent years in the field of European integration and decision-making before and after the Lisbon judgment in 2009, paying particular attention to the currently suspended OMT Decision proceedings in order to answer the question if a shift in the jurisprudence of the FCC from a euro-sceptical to a euro-phile approach has taken place.
\end{abstract}

\title{
Word length
}

The text of this research paper (excluding abstract, table of contents, footnotes and bibliography) comprises 7608 words.

\section{Subjects and topics}

European Union Law

German Constitutional Law

Jurisprudence of the FCC in the Field of European Integration and Decision-Making 


\section{Introduction}

On 14 January 2014, for the first time in its history, the German Federal Constitutional Court (FCC) decided to refer a decision to the Court of Justice of the European Union (CJEU). ${ }^{1}$ This referral, ${ }^{2}$ which concerned the issue of the legality of the European Central Bank's bond-buying practices, must be seen as "historic" with regard to European integration and the relationship between European Union law and German constitutional law, forming part of important decisions of the FCC in this field since its first euro-critical judgment, Solange I, 40 years ago. ${ }^{3}$

In line with the terminology promoted by the FCC's current president Andreas Voßkuhle, this first referral might be seen as the beginning of a new era of the "Europäischer Verfassungsgerichtsverbund", ${ }_{4}$ a term describing the European network of the FCC, the CJEU and the European Court of Human Rights ${ }^{5} .6$ The classification of this referral as either euro-phile or euro-sceptic, however, can be debated since it also infers an act of an organ of the EU to be ultra-vires: Has the FCC finally accepted the CJEU as the ultimate interpreter of EU law or not?

In order to understand the jurisprudence of the FCC in the field of European integration and decision-making during the last four decades, it must be noted that the primacy of EU law (former EEC and EC law) over national constitutional law had not been clear from the beginning of the existence of the European Economic Community (EEC) in 1957. For lack of any written primacy clause of EEC law it was the European Court of Justice (ECJ), the predecessor of the CJEU, that decided in its landmark decision Costa v E.N.E.L. in 1964 that EEC law prevailed over national (constitutional) law, arguing that it derived from the autonomous nature of the Community legal system and the need for a uniform and efficient application of EEC law in all member states. ${ }^{7}$

\footnotetext{
${ }^{1}$ See BVerfG, 2 BvR 2728/13 (14 January 2014), [2014] NJW 907 [OMT Decision], English version available at: <www.bundesverfassungsgericht.de/en/decisions/rs20140114_2bvr272813en.html>.

2 The actual referral was made on 10 February 2014, see Case C-62/14: Request for a preliminary ruling from the Bundesverfassungsgericht (Germany) lodged on 10 February 2014 - Peter Gauweiler and Others [2014] OJ C 129/11 [Gauweiler].

${ }^{3}$ See Alexander Thiele "Friendly or Unfriendly Act? The 'Historic' Referral of the Constitutional Court to the ECJ Regarding the ECB’s OMT Program” (2014) 15 German LJ 241 at 241.

4 Translation: “The European network of constitutional courts”.

${ }^{5}$ See Andreas Voßkuhle "Der europäische Verfassungsgerichtsverbund" (2010) 29 NVwZ 1 at 1 et seqq. (translation: "The European network of constitutional courts”).

${ }^{6}$ See Thiele, above $\mathrm{n} 3$, at 242.

${ }^{7}$ Case 6/64 Flaminio Costa v E.N.E.L. [1964] ECR 585 at 593 et seq. [Costa v E.N.E.L.]. Note that decision was extended by the ECJ to include constitutional norms of Member States in 1970, see Case 11/70 Internationale Handelsgesellschaft mbH v Einfuhr- und Vorratsstelle für Getreide und Futtermittel [1970] ECR 1125 at 1134 [Internationale Handelsgesellschaft].
} 
With its Solange $I^{8}$ decision in 1974, the FCC indirectly rejected the Costa $v$ E.N.E.L. decision of the ECJ, aiming at preventing an undermining of the German "supreme" constitutional law, especially of the fundamental rights recognised by the national constitution, which had no equivalent on the ECC level at that time. In the wake of this decision, the FCC was generally seen as euro-sceptical.

However, in the light of the increasing level of protection of fundamental rights on the EU level and the effectiveness of the ECJ jurisprudence, the FCC in the following rendered more judgments in the field of the relationship between EU law and German constitutional law that reversed the Solange I approach and generally accepted the primacy of EU law. In its Lisbon judgment in 2009, the FCC even developed the euro-friendly principle of "openness towards European law". ${ }^{9}$ Nonetheless, not only euro-friendly concepts were developed by the FCC in its Lisbon judgment, but also euro-sceptical concepts, such as the power of the FCC to review EU legislation where the constitutional identity was at stake (identity review) or where organs of the EU acted outside their granted power (ultra vires review).

Considering the high influence the FCC has had on the process of European integration, ${ }^{10}$ this paper aims at identifying and critiquing the lines of argumentation developed by the FCC, before (II) and after the Lisbon judgment in 2009, paying particular attention to the currently suspended OMT Decision ${ }^{11}$ proceedings, (III), in order to answer the question if a shift in the jurisprudence of the FCC from a euro-sceptical to a euro-phile approach has taken place (IV).

\section{A Step into the Right Direction? From Solange I (1974) to Lisbon's Principle of “Openness towards European Law” (2009)}

Within the German constitution, the so-called "Basic Law” (GBL), the FCC's main task is to judicially review legislation with the possibility of declaring it invalid in order to protect the values laid down in the constitution. ${ }^{12}$ In this context, it is noteworthy to mention that the GBL does not only contain a catalogue of fundamental rights (basic rights) and core

\footnotetext{
${ }^{8}$ BVerfGE 37, 271 [1974] 2 CMLR 540 [Solange I].

${ }^{9}$ BVerfGE 123, 267 [2010] 3 CMLR 13 at [201] [Lisbon].

${ }^{10}$ See Erich Vranes "German Constitutional Foundations of, and Limitations to, EU Integration: A Systematic Analysis” (2013) 14 German LJ 75 at 75. Note that in the field of the protection of fundamental rights on a supranational level also the Italian and the French (constitutional) courts were highly influential on the process of European integration.

${ }^{11}$ OMT Decision, above n 1.

12 See Basic Law 1949 (Germany) [GBL], arts 93 and 100. The FCC was established by the founders of the constitution in 1949 as the "Hüter der Verfassung", which translated literally means "the guardian of the constitution”.
} 
constitutional values to be adhered to in Germany ${ }^{13}$ but also expresses its aim to establish a “united Europe”. ${ }^{14}$

\section{A The Solange Jurisprudence and the Fundamental Rights Review}

Against this background, the first judgment of the FCC in the field of European integration and decision-making, Solange I (1974), has to be seen as euro-critical. That case concerned the conflict of an EEC regulation with fundamental rights granted by the German constitution (so called basic rights). The question arose if the FCC could judicially review an act of the EEC. The FCC ruled in favour of its own competence and further argued that for lack of an equivalent protection on the EEC level the German basic rights prevailed over secondary Community law, thus rendering it inapplicable in Germany in (the hypothetical) case of violations of the basic rights: ${ }^{15}$

As long as the integration process has not progressed so far that Community law also receives a catalogue of fundamental rights decided on by a parliament and of settled validity, which is adequate in comparison with the catalogue of fundamental rights contained in the Constitution, a reference by a court in the Federal Republic of Germany to the Bundesverfassungsgericht in judicial review proceedings, following the obtaining of a ruling of the European Court ... is admissible and necessary if the German court regards the rule of Community law which is relevant to its decision as inapplicable in the interpretation given by the European Court, because and in so far as it conflicts with one of the fundamental rights in the Constitution.

As mentioned above, this judgment established an indirect rejection of the stance taken by the ECJ in Costa v E.N.E.L. and Internationale Handelsgesellschaft concerning the (absolute) primacy of Community law and was harshly criticised as being hostile towards Europe and the idea of European integration. ${ }^{16}$ However, the background of the Solange $I$ is important to consider: The EEC's activity at that time was limited to economic relations, the EEC Treaty contained no fundamental rights, and by referring to the principle of unity and effectiveness of EEC law the ECJ ruled on several occasions that even a violation of fundamental rights protected by a national constitution could not determine the invalidity of an act of the Community. ${ }^{17}$

\footnotetext{
13 See GBL, arts 1-20.

${ }^{14}$ GBL, preamble and - since 1992 also - art 23 (1) 1.

${ }^{15}$ Solange I, above n 8, at 554 .

${ }^{16}$ See e.g. dissenting opinion of JJ Rupp, Hirsch and Wand in Solange I, above n 8, at 558 et seqq.

17 See e.g. Case 1/58 Friedrich Stork and Cie v High Authority of the European Coal and Steel Community [1959] ECR 19 at 26 [Stork]; Joint Cases 36, 37, 38 and 40/59 Präsident Ruhrkolen-Verkaufsgesellschaft mbH, Geitling Ruhrkohlen-Verkaufsgesellschaft mbH, Mausegatt Ruhrkohlen-Verkaufsgesellschaft mbH and I. Nold KG v High Authority of the European Coal and Steel Community [1960] ECR 424 at 438 [RuhrkohlenVerkaufsgesellschaft].
} 
In the following twelve years, in the light of the increasing awareness of the protection of fundamental rights on the Community level, especially through the means of the ECJ's development of a doctrine concerning these rights, such as expressed in Nold $^{18}$, the FCC changed its stance and ruled in its Solange II judgment in 1986:19

So long as the European Communities, in particular in the case law of the European Court, generally ensure effective protection of fundamental rights as against the sovereign powers of the Communities which is to be regarded as substantially similar to the protection of fundamental rights required unconditionally by the Constitution, and in so far as they generally safeguard the essential content of fundamental rights, the Federal Constitutional Court will no longer exercise its jurisdiction to decide on the applicability of secondary Community legislation cited as the legal basis for any acts of German courts or authorities within the sovereign jurisdiction of the Federal Republic of Germany, and it will no longer review such legislation by the standard of the fundamental rights contained in the Constitution.

Solange II, thus, overruled Solange I and can be seen as a more euro-friendly approach of the FCC, underlining the will of the FCC to establish a cooperation with the ECJ. A concretisation of that judgment took place in the so-called Banana Market decision, which established a very high threshold for the FCC's reserved competence to review Community law in case of conflict with German constitutional law - only if the "evolution of [Community] law, including the rulings of the European Court of Justice, has resulted in a decline below the required standard of fundamental rights after the Solange II decision”. ${ }^{20}$

\section{B New Challenges with New Treaties: The Jurisprudence of Maastricht and Lisbon}

In the wake of the Maastricht Treaty in 1992, which led to the creation of the institution EU comprising the three pillars of the EC, the Common Foreign and Security Policy and the Justice and Home Affairs, the FCC rendered its Maastricht ${ }^{21}$ judgment, which for the first time referred to the constitutional limits on the process of European integration. Apart from its well-established possibility of reviewing EU (secondary) law in order to safeguard the "essential content of the basic rights"22 concerning European decision-making, the FCC introduced a second category of its constitutional review concerning European integration: the possibility of reviewing "legal instruments of European institutions and agencies to see

${ }^{18}$ Case C 4/73 J. Nold, Kohlen- und Baustoffgroßhandlung v Commission of the European Communities [1974] ECR 491 [Nold]. The ECJ affirmed here that fundamental rights found in national constitutions of Member States and international treaties and conventions had to be taken into account by the ECJ with regard to the validity of Community law, see at 507. See also Case 36/75 Roland Rutili v Minister for the Interior [1975] ECR 1220 at 1232 [Rutili], where the ECJ underlined the key role of the European Convention for the Protection of Human Rights and Fundamental Freedoms (ECHR).

${ }^{19}$ BVerfGE 73, 339 [1987] 3 CMLR 225 at 265 [Solange II].

${ }^{20}$ BVerfGE 102, 147 [2000] 21 HRLJ 251 at headnote 1[Banana Market].

${ }^{21}$ BVerfGE 89, 155 [1994] 1 CMLR 57 [Maastricht].

${ }^{22}$ At 79. 
whether they remain within the limits of the sovereign rights conferred on them or transgress them". ${ }^{23}$ With this judgment, the FCC enlightened the theory of democratic legitimacy and conferred powers, ensuring that the German constitution, particularly art 38 in conjunction with art 20 (1), (2) GBL, ${ }^{24}$ functions as a constraint on any future transfer of sovereign powers to the EU. ${ }^{25}$ The approach of the FCC in this judgment has to be seen as more eurosceptical than before, ${ }^{26}$ emphasising in strongest terms that the primacy of EU law was merely due to the constitutionally granted powers of Germany and other member states, which still remained the "Masters of the Treaties"27.

The Treaty of Lisbon, which aimed at "enhancing the efficiency and democratic legitimacy of the Union and ... improving the coherence of its action", ${ }^{28}$ gave cause to the FCC's Lisbon judgment in 2009. ${ }^{29}$ In this judgment, the German constitutional court broadly affirmed the Maastricht judgment, but redefined the categories of constitutional review in the field of European integration and decision-making: review on the grounds of ultra vires control (ultra vires review) and review on the ground of protecting the constitutional identity (identity review). ${ }^{30}$ However, the FCC also developed the principle of "openness towards European law” (Europarechtsfreundlichkeit ${ }^{31}$ ) in this judgment: ${ }^{32}$

The constitutional mandate to realise a united Europe, which follows from art. 23.1 of the Basic Law and its Preamble ... means in particular for the German constitutional bodies that it is not left to their political discretion whether or not they participate in European integration. The Basic Law calls for European integration and an international peaceful order. Therefore, not only the principle of openness towards international law, but also the principle of openness towards European law ... applies.

With this statement, the FCC explicitly highlighted the aim of the GBL to establish a "united Europe" according to the preamble and art 23 (1) of the GBL, on the grounds of which it

\footnotetext{
23 At 89.

${ }^{24}$ Whereas art 38 ensures that the members of the German Bundestag must be elected in general, direct, free, equal and secret elections, art 20 (1) and (2) contain the constitutional principle of democracy, which is an inviolable principle of the GBL according to the eternity clause of art 79 (3) GBL.

${ }^{25}$ See Maastricht, above n 21, at 77: "This Article [art. 38] excludes the possibility, in matters to which Article 23 applies, of reducing the content of the legitimation of state power and the influence on its exercise provided by the electoral process by transferring powers to such an extent that there is a breach of the democratic principle in so far as it is declared unassailable by Article 79 (3) in conjunction with Article 20 (1) and (2)”.

26 See e.g. Günter Hirsch "Europäischer Gerichtshof und Bundesverfassungsgericht: Kooperation oder Konfrontation?” [1996] NJW 2457 at 2459 (translation: "European Court of Justice and Federal Constitutional Court: Cooperation or Confrontation?”).

${ }^{27}$ Maastricht, above n 21, at 91.

28 Treaty of Lisbon Amending the Treaty on European Union and the Treaty Establishing the European Community [2007] OJ C 306/01 (signed on 13 December 2007, entered into force 1 December 2009) [Treaty of Lisbon], preamble.

${ }^{29}$ Lisbon, above n 9.

${ }^{30}$ Further explanation of the meaning of these principles under III.

${ }^{31}$ Literal translation: "Friendliness towards European Law“.

${ }^{32}$ Lisbon, above n 9, at [201].
} 
established the principle of "openness towards European law”. By developing this principle and characterising Germany's commitment to European integration as a "constitutional mandate", the FCC in Lisbon did not only underline the major importance of the European integration process and Germany's participation in it but also implied its own willingness to give strong weight to this constitutional principle in its future judgments. ${ }^{33}$

Thus, with regard to the development from its first judgment in Solange I in 1974 to its Lisbon judgment in 2009, a shift in the jurisprudence took place from a rather hostile attitude towards a more friendly approach to the process of European integration and decisionmaking. The major concern of a protection of fundamental rights on the EU level equivalent to the German basic rights from the beginning of the jurisprudence was dropped by the FCC in the light of the efficient protection on the EU level. ${ }^{34}$

Nonetheless, it is noteworthy that the limits of this process in the form of the "ultra vires control" and the "identity control" of the FCC, also revealed some on-going euro-scepticism of the FCC on the process of European integration and decision-making. Thus, it would be too simplistic to assume that the euro-sceptical approach of the FCC has been abandoned with Lisbon.

\section{Stepping Backwards? Critiquing the Limits on the "Openness towards European Law” in the Jurisprudence after Lisbon (2009-2014)}

In how far the Lisbon judgment has also established a euro-sceptical approach, ${ }^{35}$ can only be evaluated by analysing the limits stated in Lisbon in the light of their reception in judgments rendered after Lisbon. With this landmark decision in 2009, the FCC has redefined its

\footnotetext{
${ }^{33}$ See Beke Zwingmann "The Continuing Myth of Euro-Scepticism? The German Federal Constitutional Court Two Years after Lisbon" (2012) 61 ICLR 665 at 676. Contrast Christian Tomuschat "Lisbon: Terminal of the European Integration Process? The Judgment of the German Constitutional Court of 30 June 2009” (2010) 70 ZaöRV 251at 271, who argues that the FCC in Lisbon marginalized this principle by putting the emphasis on the concept of the sovereignty of Member States.

${ }^{34}$ Granted by the ECJ and later on by the codification of fundamental rights on the EU level, such as the Charter of Fundamental Rights of the European Union 2000 [EUCFR], which became legally binding with the Treaty of Lisbon, see Consolidated Version of the Treaty on European Union 2012 (EU) [TEU], art 6 (1). Note in this context that the method of protecting the fundamental rights on the EU level is highly contested among scholars: For a protection primarily ensured by the Member States, see the "umkehrte Solange-Doktrin" ("reverse Solange doctrine"), according to which the national courts are competent as long as the national fundamental rights ensure adequate protection, by Armin von Bogdany and others "Ein Rettungsschirm für europäische Grundrechte: Grundlagen einer unionsrechtlichen Solange-Doktrin gegenüber Mitgliedsstaaten” (2012) 72 ZaöRV 45 at 46 et seqq. others (translation: “An 'Emergency Chute' for European Fundamental Rights: The Fundamentals of a Solange doctrine regulated by Union law with regard to Member States”). Contrast with the idea of a "horizontales Solange" ("horizontal Solange doctrine"), according to which the protection of fundamental rights of the EU practically takes place by Member States controlling each other horizontally while interacting, by Iris Canor "Solange horizontal: Der Schutz der EU-Grundrechte zwischen den Mitgliedstaaten" (2013) 73 ZaöRV 249 at 250 et seqq. (translation: "Solange Horizontally: The Protection of EU-Fundamental Rights among Member States”).

35 See e.g. Christian Tomuschat, above n 33, at 252.
} 
reserved competences in the field of European integration and decision-making in the following review forms: fundamental rights review, identity review and ultra vires review.

A fundamental rights review has not taken place over the last 26 years since the FCC, according to its decisions in Solange II and Banana-Market, has repeatedly stated that there has not been a general drop of human rights protection on the EU level below the standards set by the GBL. ${ }^{36}$ Attempts of euro-scepticals in Germany to make the constitutional court reconsider its Solange II/Banana-Market approach have been rejected ever since. Thus, this review competence can nowadays rather be said to be a hypothetical one, not functioning as a real limit in the field of European integration and decision-making any longer.

The other two review forms, however, have been exercised by the FCC over the last 5 years and need to be examined in more detail in the following with regard to the question as to whether they function as real limits on the process of European integration and decisionmaking. In Lisbon, the FCC held that "the ultra vires review as well as the identity review may result in ... Union law being declared inapplicable in Germany” ${ }^{37}$ and further that these two reviews were "incumbent on the Federal Constitutional Court alone". ${ }^{38}$ Thus, hereafter, these two review forms seemed to be designed as strong means limiting the principle of "openness towards EU law”. A step backwards in the process of European integration?

\section{A The Identity Review}

The FCC introduced the identity review in Lisbon by granting itself the power to ensure that the national constitutional identity would not be violated in the process of European integration and decision-making. ${ }^{39}$ According to the principle of "openness towards European law" the constitutional court implicitly invoked that a referral to the CJEU was necessary before declaring an act of a EU body to be violating the constitutional identity of Germany ${ }^{40}$.

\footnotetext{
${ }^{36}$ See e.g. BVerfGE 125, 260 [2010] NJW 833 at [181] [Data Retention], press release in English available at $<$ www.bundesverfassungsgericht.de/pressemitteilungen/bvg10-011en.html>.

${ }^{37}$ Lisbon, above n 9, at [217].

${ }^{38}$ Ibid.

${ }^{39}$ For a general tendancy of Member States to protect their national identity, see Canor, above n 34, at 250.

${ }^{40}$ Lisbon, above n 9, at [216] in connection with [309]. So far, no decision has been referred to the CJEU. For critics concerning this practice of the FCC in comparison to other (constitutional) courts of other member states, such as France, see Maja Walter "Integrationsgrenze Verfassungsidentität: Konzept und Kontrolle aus europäischer, deutscher und französischer Perspektive” (2012) 72 ZaöRV 177 at 199 (translation: "Constitutional Identity as a Limit on Integration: Concept and Control from a European, German and French Perspective”).
} 
Before discussing the decisions made by the FCC in this field, it is necessary to examine what competence the FCC reserved for itself in Lisbon by referring to the "constitutional identity" of the German Basic law. First of all, it is noteworthy to mention that there is no definition in the GBL as to what that term means. This term used by the FCC has therefore been criticised as being semantically unclear. ${ }^{41}$

The FCC held in Lisbon that the fundamental structural principles in the German constitution, namely democracy, republicanism, federalism, the rule of law and social responsibility, to be found in art 20 of the GBL, as well as the inviolable fundamental right of human dignity and other fundamental rights which are part of human dignity, to be found in art 1 of the GBL, comprise the core content of the term "constitutional identity". ${ }^{42}$ This argumentation drew on art 23 of the GBL, the "Europe-article", which stipulates: ${ }^{43}$

The establishment of the European Union, as well as changes in its treaty foundations and comparable regulations that amend or supplement this Basic Law, or make such amendments or supplements possible, shall be subject to paragraphs (2) and (3) of Article 79.

Art 79 (3) of the GBL, the so-called “eternity clause”, contains the provision that the constitutional principles laid down in art 20 and the inviolability of human dignity laid down in art 1 of the GBL shall be inadmissible. Since Germany has such an eternity clause, which aims under every circumstance to safeguard certain principles and rights, the argumentation of the FCC developed in Lisbon, declaring these "eternal” principles and rights as the core content of constitutional identity, seems to be legitimate. Against its critics, the national constitutional identity, thus, is identifiable in Germany.

In Lisbon, the FCC consequently held that these core principles and values, which formed part of the constitutional identity in Germany, could not be transferred. ${ }^{44}$ The limit hereafter established has two dimensions: firstly, on the application of existing EU law and secondly, on the future of European integration. ${ }^{45}$ Thus, in Lisbon, the FCC reserved itself the competence to review that the constitutional identity of the GBL would not be violated in the process of European integration and decision-making.

It might be arguable in how far this constitutional identity may justify an identity review in the field of European integration and decision-making. Using the constitutional identity as a limit on European integration has been criticised as interpreting this conception in a more

\footnotetext{
${ }^{41}$ Walter, above n 40, at 189.

42 See Lisbon, above n 9, at [216].

${ }^{43}$ GBL, art 23 (1) 3. English version provided by the Federal Ministry of Justice and Consumer Protection applicable at <www.gesetze-im-internet.de/englisch_gg>.

${ }^{44}$ Lisbon, above $\mathrm{n} 9$, at [211].

${ }^{45}$ Walter, above n 40 , at 183 . Note that a violation of the national identity can hereafter also be an act ultra vires.
} 
political than legal way. ${ }^{46}$ In Lisbon, the FCC further justified its competence for an identity review by making reference to art 4 (2) TEU, according to which the EU has to respect "national identities" of Member States ${ }^{47} \cdot{ }^{48}$ Even though literally, this article merely means that the EU itself is responsible for respecting "national identities" of Member States, it is acknowledged on the EU level ${ }^{49}$ and among Member States that a concretisation of what "national identity" means in every Member State can only be made on the national level. ${ }^{50}$ Furthermore, the FCC held in its pending OMT Decision case that since on the EU level, the protection of "national identity" under art 4 (2) TEU had to be taken into account as one factor only which could be balanced against other rights, the protection of the "constitutional identity", which meant more and may not be balanced against other rights, could only be guaranteed on the national level by the FCC. ${ }^{51}$ Hereafter, an identity review for Member States might be justified in the field of European integration and decision-making.

\section{Ensuring the Democratic Endorsement Process of European Integration}

The main emphasis of the FCC with regard to such an identity review in recent years has been on the protection of the democratic endorsement of the European integration process. ${ }^{52}$

In the light of the European sovereign debt crisis, the FCC ruled in 2011 concerning the bailout package for Greece and the euro-rescue package passed by the EU in 2010 that some decisions, such as decisions about public finance, were reserved for the German parliament, the Bundestag. ${ }^{53}$ The constitutional court held that the budgetary right of the Bundestag was of major importance in the democratic process, making it necessary that any large-scale financial measures agreed upon on the Union level by the government had to be approved by the Bundestag. ${ }^{54}$ Budgetary autonomy was thus established as a sub-principle of democracy and part of the constitutional identity. ${ }^{55}$ According to the FCC, the financial measures taken by the EU however, did not violate the identity of the democratic principle in Germany since a high threshold was necessary in this field, namely a substantial curtailment of the Bundestag's power, leading to a situation where the political will of voters could no longer be realised. ${ }^{56}$

\footnotetext{
${ }^{46}$ Walter, above n 40, at 190 et seq.

47 TEU, art 4 (2).

48 Lisbon, above n 9, at [210] et seq. Similar argumentation can be found in jurisprudence in France, see Walter, above $\mathrm{n} 40$, at 185 .

49 See e.g. C-208/09 Ilonka Sayn-Wittgenstein v Landeshauptmann von Wien [2010] ECR I-13693 at [83] and [87] [Sayn-Wittgenstein].

${ }^{50}$ See Walter, above $\mathrm{n} 40$, at 180 et seq.

${ }^{51}$ OMT Decision, above $\mathrm{n} 1$, at [29].

${ }^{52}$ Walter, above n 40, at 182.

53 BVerfGE 129, 124 [2011] EuZW 920 at headnotes 2 and 3 [Greek Bail-Out and Euro Rescue Package], available in English at <www.bundesverfassungsgericht.de/entscheidungen/rs20110907_2bvr098710en.html>.

${ }^{54}$ At headnote 3.

${ }^{55}$ See Zwingmann, above n 33, at 682.

${ }^{56}$ Greek Bail-Out and Euro Rescue Package, above n 53, at [100] et seqq.
} 
Additionally, the FCC strengthened the right of the Bundestag in the process of European integration by emphasising during the last two years that the Bundestag had to be provided with sufficient information by the government before decisions were made with regard to the use of budgetary resources in the EU since art 23 of the GBL conferred far-reaching rights of participation to the Bundestag. ${ }^{57}$

\section{A Restrictive Stance?}

These judgments have to be interpreted with regard to the stance of the FCC towards this review competence.

First of all, the rulings of the FCC concerning the democratic endorsement of the European integration process, which further determined the role of the legislative body, show a strong political involvement of the FCC. In this context, it must also be noted that the admissibility of constitutional complaints in this sector has been drawn by the FCC on art 38 of the GBL, the right to vote. The extension of this right to a right to elect a Bundestag with substantial decision-making powers has been criticised as an "extravagant interpretation" of this article and an attempt of the FCC to strengthen its own powers rather than individuals' rights. ${ }^{58}$ Thus, the identity review at first sight comes across as a powerful means of the FCC in the field of European integration.

However, one must also note that the FCC has shown a tendency to ultimately defer to the political will of the legislative branch with regard to the justifiability of financial commitments. ${ }^{59}$ The FCC has established a high (substantial) threshold of finding violations in the field of the democratic principle. The identity review in the field of the democratic endorsement process works as an "internal enforcement mechanism” which allows members of the German parliament as well as individuals to challenge actions taken by the federal government without prior instruction of the Parliament. ${ }^{60}$ Thus, the exercise of this competence by the FCC seems to be in line with agreements reached on the EU level concerning an increased participation of national parliaments, such as the Treaty of Lisbon. ${ }^{61}$ The substantially high threshold shows the restrictive stance taken by the FCC in this field.

\footnotetext{
57 See e.g. BVerfGE 131, 152 [2012] NVwZ 954 at headnote 2 and [146]-[147] [ESM/Euro Plus Pact]; press release concerning this judgment available in English at <www.bundesverfassungsgericht.de/pressemitteilungen/bvg12-042en.html>; see also BVerfG, 2 BvR 1390/12 (18 March 2014), [2014] BeckRS 48818 at [166] [ESM/TSCG/Measures of ECB], available in English at <www.bundesverfassungsgericht.de/entscheidungen/rs20140318_2bvr139012en.html>.

58 Tomuschat, above n 33, at 268 et seq. See also Jo Eric Khushal Murkens “'We want Our Identity Back': The Revival of National Sovereignty in the German Federal Constitutional Court's Decision on the Lisbon Treaty" [2010] P.L. 530 at 531.

${ }^{59}$ See e.g. Greek Bail-Out and Euro Rescue Package, above n 53, at headnote 5.

${ }^{60}$ See Zwingmann, above n 33, at 687.

61 At 688.
} 
Thus, the identity review of the FCC cannot be seen as a real risk concerning the European integration and decision-making process. The identity review seems to be designed rather as an inner signal to the German people to uphold the constitutional values than an outer signal to the organs or other states of the EU. ${ }^{62}$ Even though the FCC has not established general guidelines concerning the identity review yet, its findings in the field of the democratic endorsement process of the European integration suggest that the identity review is of an "exceptional character". 63 Another factor contributing to the restrictive exercise of this review competence might be that the EU values laid down in art 2 of the TEU mostly reflect the core values of the German constitution. ${ }^{64}$

\section{B The Ultra Vires Review}

The ultra-vires review, created by the FCC in its judgments in Maastricht and Lisbon, describes the FCC's reserved competence to review legal acts by European institutions and bodies in order to check if they exceed the limits of the sovereign powers granted to them. ${ }^{65}$ The principle of conferred powers can be found in art 5 (1) TEU, which stipulates that "the limits of Union competences are governed by the principle of conferral" ${ }^{66}$ With regard to art 19 (1) TEU, however, which grants the CJEU the power to "ensure that in the interpretation and application of the Treaties the law is observed", 67 it is clear that a wide ultra vires review competence of national courts would undermine the Union's basis of mutual trust and the role of the CJEU. ${ }^{68}$

After Maastricht and before Lisbon, the FCC had refused to exercise this review competence in two cases brought up before the court, one of them challenging the Council vote with regard to the introduction of the Euro on these grounds, by stating that the acts in question were obviously covered by the powers transferred to the EC. ${ }^{69}$ This former stance by the FCC has been described as "an approach similar to Solange II/Bananas in the area of human rights". ${ }^{70}$

Against this background, Lisbon seemed to introduce a far more euro-critical approach, "reversing” the former restrictive stance concerning this review competence. ${ }^{71}$ However, on

\footnotetext{
62 Ibid.

63 See Zwingmann, above n 33, at 683.

${ }^{64}$ See Walter, above n 40, at 194.

65 See Maastricht, above n 21, at 89 and Lisbon, above n 9, at [216].

66 TEU, art 5.

67 TEU, art 19.

68 See Tomuschat, above $\mathrm{n} 33$, at 279 et seq.

69 See BVerfG 2 BvR 532/98 (22 June 1998) [1998] NJW 3187 at [6] [Euro] and BVerfG 2 BvR $1210 / 98$ (17 February 2000) [2000] EuZW 445 at [23] [Alcan].

${ }^{70}$ Zwingmann, above $\mathrm{n} 33$, at 677 et seq.

${ }^{71}$ See Zwingmann, above n 33, at 678.
} 
the other hand, the FCC also inferred in Lisbon that according to the principle of "openness towards European law", the FCC had to refer to the CJEU before declaring an act of a EU body ultra vires. ${ }^{72}$ Thus, the impact of the newly "discovered" ultra vires competence of the FCC on the process of European integration and decision-making was not clear after Lisbon.

A restrictive stance of the FCC concerning its ultra vires review competence was established with the FCC's judgment in Honeywell ${ }^{73}$ in 2010. In this judgment, which arose from the ECJ ruling in Mangold $^{74}$, according to which norm in German employment law was contrary to EU law, ${ }^{75}$ the FCC established a high threshold concerning the exercise of the ultra-vires review. In a euro-friendly way, "contrary to the critics' dire predictions"76 the FCC did not find the ruling of the ECJ ultra vires act but instead made clear that an act qualified as ultravires required a breach of competences on the part of the European bodies that was "sufficiently qualified", ${ }^{77}$ i.e. a manifest breach of competences which "led to a structurally significant shift to the detriment of Member State competences". ${ }^{78}$ Furthermore, the FCC explicitly stated that before it could declare an act ultra vires the CJEU was to be afforded the opportunity to interpret the relevant EU law in question and to rule on the validity of the act in question, in the context of a preliminary ruling according to art 267 TFEU. ${ }^{79}$ Both requirements were developed by the FCC with reference to Lisbon's principle of “openness towards European law". ${ }^{80}$

So far, no act of the EU bodies has ever been declared inapplicable in Germany on ultra vires grounds. However, after in 2013 the CJEU in Åkerberg Fransson ${ }^{81}$ had interpreted the field of application of the Charter of Fundamental Rights of the EU (CFREU) widely, i.e. being applicable to practically every legislative act by member states that was related to EU law, ${ }^{82}$ the FCC referred to this CJEU's decision as an act potentially ultra vires: In its CounterTerrorism Database ${ }^{83}$ judgment, the FCC held that the Åkerberg Fransson judgment could not be read in the way that the CFREU was applicable in every case where there was some

\footnotetext{
72 See Lisbon, above n 9, at [216] in connection with [309].

73 BVerfGE 126, 286 [2011] 1 CLMR 33 [Honeywell].

${ }^{74}$ Case C-144/04 Werner Mangold v Rüdiger Helm [2005] ECR I-10013 [Mangold].

${ }^{75}$ Contrary to the principle of non-discrimination, which had been developed by the ECJ in this judgment as a principle of Community law, see Mangold, above n 74, at [75].

76 Zwingmann, above n 33, at 666.

${ }^{77}$ Honeywell, above $\mathrm{n} 73$, at [46].

${ }^{78}$ At [56].

${ }^{79}$ At [45].

80 See [43].

${ }^{81}$ Case C-617/10 Åklagaren v Hans Åkerberg Fransson [2013] 2 CMLR 46 [Åkerberg Fransson].

${ }^{82}$ See [17]-[27].

${ }^{83}$ See BVerfG, 1 BvR 1215/07 (24 April 2013), [2013] NJW 1499 [Counter-Terrorism Database]: press release concerning this judgment available in English at <www.bundesverfassungsgericht.de/pressemitteilungen/bvg13031en.html>.
} 
material connection between an act by a member state and EU law in an abstract manner, as this would amount to an evident ultra vires act. ${ }^{84}$ It might be seen critically that the FCC did not refer this question to the CJEU. Nonetheless, all in all, not declaring the Akerberg Fransson judgment ultra vires can still be seen as a euro-friendly approach of the FCC. ${ }^{85}$

\section{Affirming or Reversing its Stance? The Impact of the Pending OMT Decision Case}

In the following, it will be examined what impact the pending OMT Decision case ${ }^{86}$ has on the stance taken by the FCC concerning this review competence. The FCC might render its first ultra vires judgment in this case, which concerns the issue of the legality of the ECB's Outright Monetary Transaction decision (OMT decision) of purchasing government bonds in the secondary markets of Member States up to an unlimited amount if these Member States participate in certain reform programmes offered under the European Financial Stability Facility (EFSF) or the European Stability Mechanism (ESM). On 10 February 2014, for the first time, the FCC requested a preliminary ruling from the CJEU as to whether the OMT decision was compatible with EU primary law. ${ }^{87}$ While this action might be seen as a eurofriendly approach, the FCC also expressed in strongest terms in its decision of making a request to the CJEU on 14 January 2014, that the OMT decision of the ECB appeared to be an ultra-vires act by an organ of the EU, ${ }^{88}$ which might be seen as euro-critical.

\section{(a) Background Facts of the Case}

During the EU sovereign debt crisis in 2012, Mario Draghi, the president of the ECB, announced that the ECB was "ready to do whatever it takes to preserve the euro" ${ }^{89}$ This will was confirmed in the OMT decision made by the Governing Council of the ECB to purchase government bonds of certain Member States up to an unlimited amount under certain conditions on 6 September 2012. ${ }^{90}$ The OMT programme aims at "safeguarding an

\footnotetext{
${ }^{84}$ At [91].

${ }^{85}$ Contrast Editoral Comments “Ultra Vires - Has the Bundesverfassungsgericht shown its teeth?” (2013) 4 CM L Rev 925 at 929.

${ }^{86}$ OMT Decision, above n 1.

${ }^{87}$ See Gauweiler, above n 2.

${ }^{88}$ See OMT Decision, above n 1, at [55]-[98]. See also Federal Constitutional Court "Principal Proceedings ESM/ECB: Pronouncement of the Judgment and Request for a Preliminary Ruling to the Court of Justice of the European Union” (press release, 7 February 2014) <www.bundesverfassungsgericht.de/en/press/bvg14009en.html>: "The Senate is ... inclined to regard the OMT Decision as an ultra vires act."

${ }^{89}$ See Speech of Mario Draghi, President of the ECB, at the Global Investment Conference in London (26 July 2012) <www.ecb.europa.eu/press/key/date/2012/html/sp120726.en.html>.

90 See European Central Bank “Technical Features of Outright Monetary Transactions” (press release, 6 September 2012) <www.ecb.europa.eu/press/pr/date/2012/html/pr120906_1.en.html>. Note that before, the ECB had already set up a limited government bond purchasing programme, the Securities Market Programme (SMP), see Editorial Comments “An Unintended Side-Effect of Draghi’s Bazooka: An Opportunity to Establish
} 
appropriate monetary policy transmission and the singleness of the monetary policy". ${ }^{91}$ This OMT decision, even though not having been put into effect yet, has been effective insofar as the announcement of this decision has calmed down the sovereign bond markets ${ }^{92}$ and stemmed the speculative attack on the Euro. ${ }^{93}$

The complaints brought up before the FCC in the OMT Decision case question the legality of this decision. ${ }^{94}$ The complainants argue that this decision - being beyond the powers granted to the EU - constitutes an act ultra vires. ${ }^{95}$ The complainants therefore demand inter alia that the Bundestag and the German government be "obliged to work towards a repeal of the OMT Decision, or at least to prevent its implementation”. ${ }^{96}$

\section{(b) Evaluating the Considerations Made by the FCC}

The FCC held in its proceedings suspension decision of 14 January 2014 that the complaints were admissible and that particular questions were to be referred to the CJEU for a preliminary ruling in order to determine if the OMT decision was compatible with EU primary law. ${ }^{97}$ The considerations made by the FCC concerning the admissibility of the ultra vires review and the requirements established in Honeywell show an inconsistent approach of the court towards the process of European integration and decision-making.

With regard to the admissibility of an ultra vires review complaint, the FCC held for the first time that art 38 (1) GBL allowed a citizen to address the FCC claiming a qualified ultra vires act of an EU body which, however, did not require to include a violation of the constitutional identity. ${ }^{98}$ Furthermore, an ultra vires review in the current case was admissible based on the mere fact of a claimed omission on the part of the Bundestag. ${ }^{99}$ Before, only actions of the Bundestag had led to the admissibility of a complaint based on art 38 GBL. This double extension of the admissibility of an ultra vires review has been criticised, ${ }^{100}$ not least by the

a More Balanced Relationship Between the ECJ and Member States’ Highest Courts” (2014) 51 CM L Rev 375 at 376.

${ }^{91}$ ECB press release, above $\mathrm{n} 90$.

92 Editorial Comments, above n 90, at 376 et seq. For a case study, see e.g. Carlo Altavilla, Domenico Giannone and Michele Lenza "Working Paper No 352: The Financial and Macroeconomic Effects of the OMT Announcements" (January 2014) Centre for Studies in Economics and Finance <www.csef.it>.

${ }^{93}$ Editorial "Between Frankfurt and Karlsruhe: The Move, the Law and the Institutions” (2013) 9 EuConst 355 at 355.

${ }^{94}$ OMT Decision, above n 1.

${ }^{95}$ At [5].

${ }^{96}$ Ibid.

${ }^{97}$ See OMT Decision, above n 1.

${ }^{98}$ See [51] et seqq.

${ }^{99}$ See [49].

100 See Thiele, above n 3, at 250 et seqq; Hannes Rathke “Goldene Brücken nach Luxemburg: Die Neuvermessung des Rechtsschutzes im nationales Europaverfassungsrecht” (2014) Junge Wissenschaft im Öffentlichen Recht <www.juwiss.de> (translation: "Golden Bridges to Luxembourg: New Adjustments of the Remedies Available in the Field of 'National European Constitutional Law””). 
two dissenting constitutional judges in that case, JJ Lübbe-Wolf and Gerhardt. ${ }^{101}$ According to the latter judge, such a low procedural threshold concerning the ultra vires review bears the risk of opening the door "to a general right to have the laws enforced..., which the Basic Law does not contain". ${ }^{102}$ However, since the FCC explicitly invoked in that decision that such a general right of citizens was not intended and a certain threshold had still to be met ${ }^{103}$ this (double) extension of the admissibility might still be seen as in line with the FCC's former stance taken in the field of its ultra vires review.

Apart from this, it is not clear in how far this decision of the FCC adjusted its former restrictive stance taken concerning the high requirements established in Honeywell:

On the one hand, it must be noted that the FCC expressly stated that an ultra vires review would only take place according to the strict procedural and material requirements established in Honeywell, ${ }^{104}$ thus (implicitly) acknowledging its former restrictive stance. The strict procedural requirement of Honeywell can furthermore be seen as been fulfilled in the current case by the FCC since it held that it would find the act in question ultra vires only "subject to the interpretation by the Court of Justice of the European Union"105 and actually decided to refer controversial questions to the CJEU first before declaring an act ultra vires. ${ }^{106}$

On the other hand, it might be questioned in how far the strict substantial requirements established in Honeywell were upheld in the current case. Even though formally, the FCC claimed that the OMT decision would be assumed as an act ultra vires according to the strict substantial criteria set in Honeywell, i.e. that there was a manifest breach of the transferral of powers that lead to a structurally significant shift in the allocation of powers detrimental to the Member States, materially, some of the reasons given by the FCC on this point might be seen as not meeting the strict criteria set in Honeywell:

Following a two-step approach, the FCC pointed out first what constituted the breach and second why this breach constituted a manifest and structurally significant transgression of powers according to Honeywell.

Within its first step, the FCC argued that, in its view, a breach of transferred powers was given since the OTM decision was incompatible with EU primary law, violating the ECB's

${ }^{101}$ See OMT Decision, above $\mathrm{n}$ 1, at F.

${ }^{102} \mathrm{~F}$., dissenting opinion of Gerhard, at [6].

${ }^{103}$ At [52]: "Art 38 sec. 1 sentence 1 GG does not entail a right that reaches beyond safeguarding the abovementioned rights and that would let citizens have the legality of decisions taken by a democratic majority reviewed by the Federal Constitutional Court.”

${ }^{104}$ At [24].

${ }^{105}$ At [55].

${ }^{106}$ See Editorial Comments, above n 90, at 382. 
monetary policy mandate ex arts 119 and 127 (1), (2) TFEU ${ }^{107}$ as well as the prohibition of monetary financing of the budget ex art 123 TFEU. ${ }^{108}$ Whereas the first assumed violation was founded on various reasons regarding the specific techniques set out in the OMT programme, the latter assumed violation concerned the OMT programme's lack of a quantitative limit for the purchase of Member States’ government bonds. ${ }^{109}$

However, it is noteworthy in this context that the FCC itself also considered the possibility of an interpretation of the OMT decision in conformity with EU primary law. ${ }^{110}$ According to the FCC, such a restrictive interpretation of the OMT decision required inter alia a limitation on the purchase of government bonds, an exclusion of a debt cut possibility and a guarantee that the OMT decision would not undermine the EFSF and ESM programmes. ${ }^{111}$ Thus, even though the FCC itself seems inclined to find the OMT decision violating EU law, the FCC's will of cooperating with the CJEU on this question is also clearly visible. ${ }^{112}$

Within its second step, the FCC argued that these violations - if occurring - would definitely constitute such a manifest and structurally significant transgression of powers as needed in order to constitute an act ultra vires according to Honeywell, a reasoning which might (partly) be seen as euro-critical: ${ }^{113}$

Concerning the monetary policy mandate of the ECB, the FCC held that the ECB was not authorised to pursue its own economic policy but may only support the general economic policies in the Union. The OMT decision, however, had to be qualified as an independent act of economic policy, encroaching upon the competences of Member States. ${ }^{114}$ In the terms of the FCC, the OMT decision was a structurally significant act as the decision itself 115

could be superimposed onto assistance measures which are part of the "Euro rescue policy" and which ... belong to the core aspects of the Member States' economic policy responsibilities (cf. Art. 136 sec. 3 TFEU)

and the outright monetary transactions could ${ }^{116}$

\footnotetext{
${ }^{107}$ Consolidated Version of the Treaty on the Functioning of the European Union 2012 (EU) [TFEU].

108 See Gauweiler, above n 2, at first question. See also OMT Decision, above n 1, at [55].

109 Ibid.

110 See [99] et seq.

111 At [100]. Note that these suggestions were made by ECB representatives themselves in the current proceedings.

112 See Sebastian Müller-Franken "Vereinbarkeit des Ankaufs von Staatsanleihen durch EZB mit EU-Recht Vorlage an den EuGH“ [2014] NVwZ 514 at 515 (translation: “Compatibility of the ECB's Programme of Purchasing Government Bonds with EU-Law - Referral to the CJEU” ).

113 See Thiele, above n 3, at 244 et seq.; 254 et seq.

114 See [39].

${ }^{115}$ At [40].

116 At [41].
} 
lead to a considerable redistribution between ... the Member States, and can thus gain effects of a system of fiscal redistribution, which is not entailed in the integration programme of the European Treaties.

The position of the FCC expressed here is clearly an ordoliberalistic one, strictly distinguishing between monetary policy and economic policy and demanding the ECB to be independent from government's economic policy. ${ }^{117}$ Based on this distinction, according to the FCC, the OMT decision being primarily an economic means could not be seen as a monetary policy means even though it also pursued monetary policy objectives. ${ }^{118}$ This ordoliberalistic position might be seen as controversial on the EU level with regard to the interdependences of these two policies. ${ }^{119}$ Even though the literal reading of arts 119, 127 (1), (2) TFEU might justify an ordoliberalistic interpretation of the ECB's monetary policy mandate, ${ }^{120}$ the CJEU has acknowledged the interdependences of the two policies: In Pringle, ${ }^{121}$ the CJEU interpreted monetary policy of the Union in an extensive way, ${ }^{122}$ defining it by reference to its objectives rather than to its instruments. ${ }^{123}$ Thus, if one bears in mind the stance taken by the CJEU and the facts in this case that the objective of the OMT decision was to correct a disruption of the monetary policy transmission mechanism in order to contribute to the stability of the monetary union, ${ }^{124}$ there are doubts as to whether the FCC's ordoliberalistic interpretation of these EU norms was reasonable. ${ }^{125}$ Therefore, the strict Honeywell-requirements do not seem fulfilled in this reasoning.

By contrast, with regard to the prohibition of monetary financing of the budget ex art 123 TFEU, the argumentation given by the FCC seems to withstand the strict requirements established in Honeywell. The FCC held that the violation would be manifest because EU primary law "stipulates an explicit prohibition of monetary financing of the budget and thus unequivocally excludes such powers of the European Central Bank” and that it would lead to a significant shift to the detriment of Member States since the OMT decision - allowing for unlimited bond purchases of government bonds by the ECB - would undermine "the overall

\footnotetext{
117 Matthias Goldmann "Wotans langsamer Abschied? Von der Möglichkeit einer Integrationsrechtsprechung für die pluralistische Bürgergesellschaft” (2014) Junge Wissenschaft im Öffentlichen Recht <www.juwiss.de> (translation: "Wotan's steady Good-bye? About the Possibility of a Jurisprudence of Integration for the pluralistic Civil Society").

${ }^{118}$ See OMT Decision, above n 1, at [64] et seqq.; [95] et seqq.

${ }^{119}$ Editorial Comments, above n 90, at 378 et seq.

${ }^{120}$ See Müller-Franken, above n 112, at 514.

${ }^{121}$ Case C-370/12 Thomas Pringle v Government of Ireland and the Attorney General (27 November 2012) [Pringle].

122 See Sebastian Piecha "Historisch: Was bedeutet die Vorlage des BVerfG für das Kooperationsverhältnis mit dem EuGH?” (2014) Junge Wissenschaft im Öffentlichen Recht <www.juwiss.de> (translation: "Historic: Of what Significance is the Referral of the FCC with regard to the cooperative relationship with the CJEU?”).

${ }^{123}$ Pringle, above $\mathrm{n} 121$, at at [54] et seqq.

${ }^{124}$ See on this latter point Thiele, above $\mathrm{n} 3$, at 256 et seq.

125 See Goldmann, above n 117.
} 
budgetary responsibility of the German Bundestag”. ${ }^{126}$ Even though the stance of the FCC taken here might at first also seem rather euro-critical if one assumes that Pringle ${ }^{127}$ has established a restrictive interpretation of the CJEU concerning the prohibition of monetary funding, ${ }^{128}$ but the FCC assumed that art 123 TFEU expressed "a broader prohibition of monetary budget financing"129, the fact that the OMT decision did not contain any limits in terms of purchasing Member States government funds seems highly likely to establish a manifest violation of this prohibition, circumventing this prohibition by a functionally equivalent measure and significantly undermining the overall budgetary responsibility of the Bundestag. ${ }^{130}$ Therefore, the reasoning of the FCC seems rather an attempt to preserve its constitutional identity ${ }^{131}$ than to criticise actions of EU bodies.

To conclude the assessment of the FCC in the current OMT decision case, it must be noted that there are both euro-friendly as well as euro-critical approaches included in the considerations given by the court. Whereas the extension of the admissibility of an ultra vires review complaint and the consideration of seeing the OMT decision ultra vires (with regard to the monetary policy mandate) might be seen as euro-critical, the referral to the CJEU itself, the attempt to interpret the OMT decision in a way conformant to EU primary law and the reference to the strict Honeywell criteria underline the ultimate euro-friendly will of the FCC, to enhance the cooperation with the CJEU and to promote the process of European integration and decision-making. ${ }^{132}$ Thus, so far, this pending case does not seem to have changed the restrictive stance taken by the FCC concerning the exercise of this review competence.

\section{(c) Concluding Remarks Concerning the "Worst Case Scenario"}

Even though the OMT Decision case has generally confirmed the restrictive stance taken by the FCC concerning its ultra vires review, it remains unclear what consequences it will have on the European integration and decision-making process if the current litigation leads to two controversial judgments, the CJEU finding the OMT decision not ultra vires but the FCC

\footnotetext{
126 At [43].

127 See Pringle, above n 121, at [123] et seqq.; [132].

128 See Piecha, above n 122. See also Daniel Thym “Anmerkung zum Urteil des EuGH vom 27.11.2012 (C370/12): Zur Frage nach der Vereinbarkeit des ESM mit dem Unionsrecht” [2013] JZ 259 at 263 (translation: “A Comment on the CJEU's Judgment of 27.11.2012 (C-370/12): Questioning the Compatibility of the ESM with Union Law”).

${ }^{129}$ OMT Decision, above n 1, at [85].

${ }^{130}$ See Sebastian Müller-Franken "Eilanträge gegen Ratifikation von ESM-Vertrag und Fiskalpakt überwiegend erfolglos: Anmerkung” [2012] 3161 at 1362 (translation: Urgent Requests Concerning Ratification of the ESM_Treaty and the Fiscal Pact are predominantly without Success: An Annotation”). Contrast Thiele, above $\mathrm{n}$ 3 , at 261 et seq.

${ }^{131}$ Note that the FCC left the question open in how far the OMT decision would constitute a violation of the national constitutional identity, see [22], [27] et seqq. and [102] et seq.

${ }^{132}$ Contrast Thiele, above $\mathrm{n} 3$, at 250, who argues that the considerations made by the FCC were primarily euro"unfriendly".
} 
finding the act ultra vires. In line with its generally friendly interpretation concerning actions of EU organs and bodies, as seen in Mangold and Pringle, the CJEU is highly likely to rule that the OMT decision is conformant to EU primary law. ${ }^{133}$ In the "worst case scenario" this could be made by the CJEU without taking into account the interpretation suggested by the FCC, which, then, would "force" the FCC to render its first ultra vires judgment.

In such a situation, under national law, the Bundestag and the German government would have an obligation either to confer more powers on the EU, which is unlikely to happen, or attempt to reverse the OMT decision or at least forbid its implementation in Germany. ${ }^{134}$ Under EU law, however, these German organs would have a duty to fulfil the implementation of the OMT decision, risking otherwise an infringement procedure according to arts 258 et seqq. TFEU for Germany having breached its obligations under EU law.

This paradox situation into which national German organs could be led as a result of controversial judgments on the national and the EU level underlines the need to resolve the controversial question who the ultimate interpreter of finding an act of EU bodies ultra vires is: the FCC or the CJEU? This question is not only a question of power but also a question concerning the burden of rendering possibly uncorrectable misjudgements. ${ }^{135}$

The current case will hopefully strengthen the relationship between the CJEU and the FCC in that the competences of the respective courts will be further determined in the following proceedings and will contribute to a development of a strong -preferably symbioticcooperation of the respective courts in the future - similar to the one that has taken place in the field of fundamental rights review. ${ }^{136}$

\section{Result of Analysis}

Overall, the ultra-vires review has been less invoked than feared by many critics of the Lisbon judgment. ${ }^{137}$ Even though on the procedural side, the threshold established by the FCC has been lowered over time, especially with the current decision about the admissibility in the OMT Decision case, on the substantial side, the high threshold established by the FCC in Honeywell has been upheld until at present. Thus, an ultra vires control competence can only be exercised in extreme circumstances since the FCC does not conceive itself as a eurosupervision instance. ${ }^{138}$ Nonetheless, the reaction of the FCC to Akerberg Fransson and the

\footnotetext{
133 See Piecha, above n 122.

${ }^{134}$ See OMT Decision, above $n 1$, at [44] et seqq.

135 See Hirsch, above n 26, at 2457; Editorial Comments, above n 90, at 385.

${ }^{136}$ See Piecha, above n 122; Editorial Comments, above n 90, at 386.

137 See Zwingmann, above n 33, at 680 et seq.

138 See Andreas Voßkuhle "Der Rechtsanwalt und das Bundesverfassungsgericht: Aktuelle Herausforderungen der Verfassungsrechtsprechung” [2013] NJW 1329 at 1331 (translation: “The Lawyer and the Federal Constitutional Court: Current Challenges of the Jurisprudence in the field of Constitutional Law”).
} 
current referral to the ECJ once more show the great political involvement of the German constitutional court, which might be called into question.

\section{A Need for Judicial Activism? - Closing Remarks Concerning the Two Review Competences}

As seen above, in both the identity review and the ultra vires review the FCC renders highly political judgments, an approach, which has been criticised as "judicial activism". ${ }^{139}$ Unlike other countries, Germany has no "political question doctrine" which would limit the (constitutional) court's capacity of deciding politically contentious issues with regard to the judges' weak democratic legitimacy. ${ }^{140}$ If one bears in mind that Germany is de facto one of the leaders concerning the European integration process, having a "decisive say in the development of policies for the Union as a whole”, ${ }^{141}$ one might legitimately ask the question if the FCC should play such an important role in this process or if this should be left to politicians. ${ }^{142}$

However, even without a political question doctrine, the FCC has always shown ultimate deference to the political will of the German state organs in the European integration process. The strengthening of the Bundestag's rights in its jurisprudence can rather be seen as an example of having even positively contributed to the application of the principle of democracy and the endorsement of the majority's will. This might change if the FCC rendered its first ultra vires judgment in the OMT decision case, demanding actions from the Bundestag contrary to the Bundestag's actual will. ${ }^{143}$ But this judicial activism seems adequate in the current crisis if the actions of the FCC are seen as a legitimate check on the legislative power, demanding for a clear legal basis for actions on the EU level and condemning a policy of "whatever it takes" (to rescue the Euro) in the integration process. ${ }^{144}$

Generally speaking, the FCC’s establishment of the ultra vires review and the identity review under high thresholds contributes to safeguarding the core principles and rights on the national sovereign level and to the enhancement of the European integration process, ${ }^{145}$ both

\footnotetext{
139 See e.g. Tomuschat, above n 33, at 282; Cormac Mac Amhlaigh "Does Germany need a political questions doctrine” (21 February 2014) Eutopialaw <www.eutopialaw.com>. See also Khushal Murkens, above n 58, at 548 et seqq.

${ }^{140}$ See e.g. Mac Amhlaigh, above n 139, who demands for a political question doctrine in Germany.

141 See e.g. Tomuschat, above n 33, at 270.

142 See Mac Amhlaigh, above n 139; Russel Miller "The Rumble in Karlsruhe: The German Federal Constitutional Court's Historic OMT Case” (7 February 2014) Int'l J Const L Blog <www.iconnectblog.com>.

143 See Miller, above n 142, who argues that such a decision would be judicial activism at its best, more decisive than any other decision before and "the end of 'so long as' and 'yes...but'” in the field of the European integration process.

144 See Müller-Franken, above n 112, at 515.

145 See Zwingmann, above n 33, at 688.
} 
of which are expressly laid down in the GBL. ${ }^{146}$ Thus, the FCC has not stepped backwards since Lisbon but rather reacted to new challenges occurring in the integration process.

\section{Conclusion}

As a "guardian of the German constitution" 147 the FCC has to ensure the enhancement of the process of European integration and decision-making in accordance with the limits set by the German constitution. Due to the highly abstract norms of the German constitution, the FCC is sometimes forced to render highly political judgments, like such concerning mechanisms established by the EU bodies to overcome the current European sovereign debt crisis. A clear position of the FCC concerning the European integration and decision-making process, however, is hard to find.

On the one hand, the FCC has shown a euro-sceptical stance: until at present, contrary to the jurisprudence of the CJEU and to Declaration 17 of the Treaty of Lisbon ${ }^{148}$, it has not accepted the absolute primacy of EU law. Furthermore, the three reserved competences established in Solange II, Maastricht and Lisbon, namely the fundamental rights review, the identity review and the ultra vires review, contribute to the perception of the FCC as being rather euro-sceptical.

On the other hand, a euro-phile tendency of the FCC can be observed: in the past 40 years of its jurisprudence, a general shift of the FCC's position has taken place. Since Solange II in 1986, for instance, the FCC's competence reserved for the case of a merely inadequate protection of fundamental rights on the EU level has no longer been exercised. In Lisbon, the FCC even created the principle of “openness towards European law”. In addition, even eurocritical concepts established in Lisbon, namely the identity review and the ultra vires review, require a high threshold - at least substantially - as having been specified by the FCC jurisprudence over the past five years.

To conclude, it is not adequate to categorise the stance of the FCC as either euro-sceptical or euro-phile. Its overall position might rather be characterised as euro-friendly. Even though the FCC is not inclined to give up all its competences, it provides "considerable practical support" of both application and enforcement of EU law in Germany and the enhancement of the European integration process. ${ }^{149}$ The FCC nowadays generally accepts the primacy of Union law as long as no threat to constitutional rights or "unwarranted intrusions into areas

\footnotetext{
146 See GBL, arts 20 in conjunction with 79 (3) for core values and GBL, preamble and art 23 for European integration process.

${ }^{147}$ See above $n 10$.

148 Treaty of Lisbon, above n 28, 17. Declaration Concerning Primacy at 256.

149 Zwingmann, above n 33, at 666.
} 
within the legislative jurisdiction” of Germany are taking place. ${ }^{150}$ Recent considerations of the FCC, such as those made in the pending OMT Decision case, seem necessary in order to both safeguard the constitutional values provided for by the German constitution and to prevent a collapse of the EU and thus may not be seen as euro-critical per se but rather as contributing in the long run to the European integration and decision-making process. The fear that uniformity of EU law is at risk by the jurisprudence of the $\mathrm{FCC}^{151}$ has not been justified yet. In fact, the realisation of a multilateral cooperation of courts may encourage checks and balances on the CJEU and the constitutional courts of the Member States and therefore be seen as highly valuable in times of crises, such as the unprecedented EU socialeconomic crisis. ${ }^{152}$

150 Josephine Steiner and Lorna Woods EU Law (10 $10^{\text {th }}$ ed, Oxford University Press, Oxford, New York, 2009) at 101.

151 See e.g. Tomuschat, above n 33, at 261.

152 See Walter, above n 40, at 197, particularly concerned with the protection of the national constitutional identity. More generally on this point, see Giacinto della Cananea "Is European Constitutionalism Really 'Multilevel’?” (2010) 70 ZaöRV 283 at 297 et seq. 


\section{BIBLIOGRAPHY}

\section{PRIMARY SOURCES}

\section{A Cases \\ 1 European Union}

Case 1/58 Friedrich Stork and Cie v High Authority of the European Coal and Steel Community [1959] ECR 19.

Joint Cases 36, 37, 38 and 40/59 Präsident Ruhrkolen-Verkaufsgesellschaft mbH, Geitling Ruhrkohlen-Verkaufsgesellschaft mbH, Mausegatt Ruhrkohlen-Verkaufsgesellschaft $\mathrm{mbH}$ and I. Nold KG v High Authority of the European Coal and Steel Community [1960] ECR 424.

Case 6/64 Flaminio Costa v E.N.E.L [1964] ECR 585.

Case 11/70 Internationale Handelsgesellschaft $m b H \vee$ Einfuhr- und Vorratsstelle für Getreide und Futtermittel [1970] ECR 1125.

Case 36/75 Roland Rutili v Minister for the Interior [1975] ECR 1220.

Case C 4/73 J. Nold, Kohlen- und Baustoffgroßhandlung $v$ Commission of the European Communities [1974] ECR 491.

Case C-144/04 Werner Mangold v Rüdiger Helm [2005] ECR I-10013.

C-208/09 Ilonka Sayn-Wittgenstein v Landeshauptmann von Wien [2010] ECR I-13693.

Case C-617/10 Åklagaren v Hans Åkerberg Fransson [2013] 2 CMLR 46.

Case C-370/12 Thomas Pringle v Government of Ireland and the Attorney General (27 November 2012).

Case C-62/14: Request for a preliminary ruling from the Bundesverfassungsgericht (Germany) lodged on 10 February 2014 - Peter Gauweiler and Others [2014] OJ C 129/11.

2 Germany

BVerfGE 37, 271 [1974] 2 CMLR 540 [Solange I].

BVerfGE 73, 339 [1987] 3 CMLR 225 [Solange II].

BVerfGE 89, 155 [1994] 1 CMLR 57 [Maastricht].

BVerfG 2 BvR 532/98 (22 June 1998) [1998] NJW 3187 [Euro]. 
BVerfG 2 BvR 1210/98 (17 February 2000) [2000] EuZW 445 [Alcan].

BVerfGE 102, 147 [2000] 21 HRLJ 251 [Banana Market].

BVerfGE 123, 267 [2010] 3 CMLR 13 [Lisbon].

BVerfGE 125, 260 [2010] NJW 833 [Data Retention].

BVerfGE 126, 286 [2011] 1CLMR 33 [Honeywell].

BVerfGE 129, 124 [2011] EuZW 920 [Greek Bail-Out and Euro Rescue Package].

BVerfGE 131, 152 [2012] NVwZ 954 [ESM/Euro Plus Pact].

BVerfG 1 BvR 1215/07 (24 April 2013) [2013] NJW 1499 [Counter-Terrorism Database].

BVerfG 2 BvR 2728/13 (14 January 2014) [2014] NJW 907 [OMT Decision].

BVerfG 2 BvR 1390/12 (18 March 2014) [2014] BeckRS 48818 [ESM/TSCG/Measures of $E C B]$.

\section{B Legislation}

1 European Union

Consolidated Version of the Treaty on European Union 2012 (EU).

Consolidated Version of the Treaty on the Functioning of the European Union 2012 (EU).

$2 \quad$ Germany

Basic Law 1949 (Germany).

\section{Treaties}

Treaty of Lisbon Amending the Treaty on European Union and the Treaty Establishing the European Community [2007] OJ C 306/01 (signed on 13 December 2007, entered into force 1 December 2009).

\section{SECONDARY SOURCES}

\section{A Texts}

Josephine Steiner and Lorna Woods EU Law $\left(10^{\text {th }}\right.$ ed , Oxford University Press, Oxford, New York, 2009). 


\section{B Journal Articles}

Editorial "Between Frankfurt and Karlsruhe: The Move, the Law and the Institutions” (2013) 9 EuConst 355 at 355.

Editorial Comments “An Unintended Side-Effect of Draghi's Bazooka: An Opportunity to Establish a More Balanced Relationship Between the ECJ and Member States' Highest Courts” (2014) 51 CM L Rev 375.

Editorial Comments "Ultra Vires - Has the Bundesverfassungsgericht shown its teeth?" (2013) 4 CM L Rev 925.

Armin von Bogdany and others "Ein Rettungsschirm für europäische Grundrechte: Grundlagen einer unionsrechtlichen Solange-Doktrin gegenüber Mitgliedsstaaten” (2012) 72 ZaöRV 45.

Giacinto della Cananea “Is European Constitutionalism Really 'Multilevel’?” (2010) 70 ZaöRV 283.

Iris Canor "Solange horizontal: Der Schutz der EU-Grundrechte zwischen den Mitgliedstaaten” (2013) 73 ZaöRV 249.

Günter Hirsch "Europäischer Gerichtshof und Bundesverfassungsgericht: Kooperation oder Konfrontation?” [1996] NJW 2457.

Jo Eric Khushal Murkens “'We want Our Identity Back': The Revival of National Sovereignty in the German Federal Constitutional Court's Decision on the Lisbon Treaty” [2010] P.L. 530.

Sebastian Müller-Franken "Vereinbarkeit des Ankaufs von Staatsanleihen durch EZB mit EU-Recht - Vorlage an den EuGH: Anmerkung“ [2014] NVwZ 514.

Sebastian Müller-Franken "Eilanträge gegen Ratifikation von ESM-Vertrag und Fiskalpakt überwiedgend erfolglos: Anmerkung” [2012] 3161.

Alexander Thiele "Friendly or Unfriendly Act? The 'Historic' Referral of the Constitutional Court to the ECJ Regarding the ECB’s OMT Program” (2014) 15 German LJ 241.

Daniel Thym “Anmerkung zum Urteil des EuGH vom 27.11.2012 (C-370/12): Zur Frage nach der Vereinbarkeit des ESM mit dem Unionsrecht” [2013] JZ 259.

Christian Tomuschat "Lisbon: Terminal of the European Integration Process? The Judgment of the German Constitutional Court of 30 June 2009” (2010) 70 ZaöRV 251.

Andreas Voßkuhle “Der europäische Verfassungsgerichtsverbund” (2010) 29 NVwZ 1. 
Andreas Voßkuhle "Der Rechtsanwalt und das Bundesverfassungsgericht: Aktuelle Herausforderungen der Verfassungsrechtsprechung” [2013] NJW.

Erich Vranes "German Constitutional Foundations of, and Limitations to, EU Integration: A Systematic Analysis” (2013) 14 German LJ 75.

Maja Walter "Integrationsgrenze Verfassungsidentität: Konzept und Kontrolle aus europäischer, deutscher und französischer Perspektive” (2012) 72 ZaöRV 177.

Beke Zwingmann "The Continuing Myth of Euro-Scepticism? The German Federal Constitutional Court Two Years after Lisbon” (2012) 61 ICLR 665.

\section{B Internet Materials}

$1 \quad$ Press Releases

European Central Bank “Technical Features of Outright Monetary Transactions” (press release, 6 September 2012)

<www.ecb.europa.eu/press/pr/date/2012/html/pr120906_1.en.html>.

Federal Constitutional Court "Principal Proceedings ESM/ECB: Pronouncement of the Judgment and Request for a Preliminary Ruling to the Court of Justice of the European Union” (press release, 7 February 2014)

$<$ www.bundesverfassungsgericht.de/en/press/bvg14-009en.html>.

\section{$2 \quad$ Speeches}

Speech of Mario Draghi, President of the ECB, at the Global Investment Conference in London (26 July 2012) <www.ecb.europa.eu/press/key/date/2012/html/sp120726.en.html>.

\section{$3 \quad$ Other Materials}

Carlo Altavilla, Domenico Giannone and Michele Lenza “Working Paper No 352: The Financial and Macroeconomic Effects of the OMT Announcements” (January 2014) Centre for Studies in Economics and Finance <www.csef.it> .

Matthias Goldmann "Wotans langsamer Abschied? Von der Möglichkeit einer Integrationsrechtsprechung für die pluralistische Bürgergesellschaft” (2014) Junge Wissenschaft im Öffentlichen Recht <www.juwiss.de>.

Cormac Mac Amhlaigh "Does Germany need a political questions doctrine” (21 February 2014) Eutopialaw <www.eutopialaw.com>.

Russel Miller “The Rumble in Karlsruhe: The German Federal Constitutional Court's Historic OMT Case” (7 February 2014) Int'l J Const L Blog <www.iconnectblog.com>. 
Sebastian Piecha "Historisch: Was bedeutet die Vorlage des BVerfG für das Kooperationsverhältnis mit dem EuGH?” (2014) Junge Wissenschaft im Öffentlichen Recht $<$ www.juwiss.de $>$.

Hannes Rathke "Goldene Brücken nach Luxemburg: Die Neuvermessung des Rechtsschutzes im nationales Europaverfassungsrecht” (2014) Junge Wissenschaft im Öffentlichen Recht $<$ www.juwiss.de $>$. 